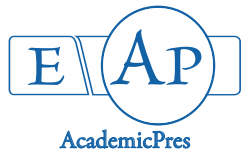

Adeniran SA et al. (2020)

Notulae Scientia Biologicae 12(3):637-645

DOI: $10.15835 / \mathrm{nsb} 12310686$

Research Article

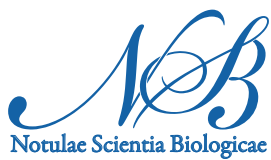

\title{
Comparative foliar epidermal morphology of Isolona Engl. (Annonaceae)
}

\section{Sunday A. ADENIRAN ${ }^{1 *}$, Akeem B. KADIRI ${ }^{2}$, James D. OLOWOKUDEJO ${ }^{2}$}

\footnotetext{
${ }^{1}$ University of Ilorin, Department Plant Biology, Ilorin Nigeria; adeniran.sa@unilorin.edu.ng (*corresponding author) ${ }^{2}$ University of Lagos, Department Botany, AkokaYabaLagos, Nigeria; akadiri@unilag.edu.ng; jolowokudejo@unilag.edu.ng
}

\begin{abstract}
A qualitative micromorphological assessment of the seven species of Isolona occurring in Nigeria and the Cameroons was undertaken with the aid of light microscope. The stomatal cells are particularly useful, providing stable characters which can be reliably employed in distinguishing the species. Hypostomatic leaves and paracytic stomatal type are generic constant. Possession of only paracytic stomata is characteristic of $I$. dewevrei whereas other species may have in addition another type such as $1+2$ laterocytic stomatal type found only in I. zenkeri and presence of brachyparacytic stomata which shows relatedness of I. campanulata, I. congolana, I. hexaloba, I. pleurocarpus and I. thonneri. The epidermal surfaces appeared glabrous but an indication of hairs is shown by the presence of a glandular trichome base only in $I$. hexaloba. The epidermal cell characters such as epidermal cell shapes and anticlinal wall patterns seem to intergrade and they are not as definite as the stomatal cells. However, a combination of these features will be helpful in defining the species better and their leaf fragments can be differentiated based on the various characters studied for effective utilization in herbal medicinal research.
\end{abstract}

Keywords: epidermis; leaf; Isolona; micromorphology; stomata

\section{Introduction}

Annonaceae Juss. are a pantropical family of trees, shrubs, and lianas belonging to the order Magnoliales (APGII, 2003). The family comprises cca. 42 genera and around 400 species (Maas et al., 2003; Bremer et al., 2009; Smith et al., 2010; Couvreur et al., 2012; Zeng et al., 2014;). Compared to the Neotropical and SouthEast Asian Annonaceae, the African taxa are largely understudied (Maas et al., 2003; Couvreur et al., 2006; Couvreur et al., 2008). One of the African genera in this category is Isolona Engl., a sizeable genus with ca.21 species distributed across the tropical zone. Isolona Engl. flowers are hermaphroditic and are unusual as all six petals are basally connate, forming a single whorl; although an enclosed pollination chamber does not form, the petals are inwardly curved to form a loose chamber (Couvreur, 2009). The petals are yellowish or reddish and are often darker towards the inside of the flower. Relatively little is known about the reproductive biology, although the flowers of I. campanulata Engl. and Diels have been shown to be protogynous, with the reproductive phases extending over a 2-day (or possibly 3-day) period, with diurnal receptivity (Gottsberger et 
al., 2011). The species are mainly trees and there are accounts on exomorphology (Maas et al., 2003; Couvreur, 2009), but data on the anatomy are very sparse (Metcalfe and Chalk, 1950; 1979). Together with the genus Monodora Dunal, it nested in the same clade (Richardson et al., 2004) based on morphological, palynological and molecular data, some of the species are often confused and, in the past, they have been traditionally placed in the same sub family Monodoroideae Kostel. based on true syncarpous ovary.

In search for additional identification criteria, the characteristics of the leaf epidermis of 7 African species occurring in Nigeria and Cameroons were investigated for this study with a view to describe the species better and update the existing data on the family at large.

\section{Materials and Methods}

Seven species of Isolona obtained at the Forestry Herbarium Ibadan, Nigeria (FHI) and National Herbarium Yaounde, Cameroon (YA, IH) were used for the study (Table 1). The herbarium abbreviations follow Holmgren and Holmgren (2003).

Table 1. List of species used for the study

\begin{tabular}{|c|c|c|c|}
\hline S/N & Taxa & Collector & Date of Collection \\
\hline 1 & Isolona campanulata & P.T. Francis & Dec. 1945 \\
\hline 2 & I. congolana & Westphal & $15 / 5 / 78$ \\
\hline 3 & I. dewevrei & R. Letouvzey & $8 / 7 / 75$ \\
\hline 4 & I. hexaloba & R. Letouvzey & $16 / 5 / 63$ \\
\hline 5 & I. pleurocarpus & R. Letouvzey & $16 / 4 / 68$ \\
\hline 6 & I. thonneri & R. Letouvzey & $23 / 3 / 70$ \\
\hline 7 & I. zenkeri & Endengle Elais & $1955-1956$ \\
\hline
\end{tabular}

\section{Leaf epidermal preparation}

A total of 5 leaf samples each and 20 microscope fields were examined for constancy of characters. Dried herbarium samples were used. $1-5 \mathrm{~cm}^{2}$ portions of the leaves were cut from the standard median part of the matured leaves, the midway between apex and base portion of the leaf lamina near the mid-rib following the approaches of Ogundipe and Olatunji (1991), Olowokudejo (1993), Ayodele (2000), Kadiri (2003). Leaves were hydrated by boiling in water and soaked in concentrated trioxonitrate $(\mathrm{v})$ acid $\left(\mathrm{HNO}_{3}\right)$ in glass bottles for about 8-24 hours to macerate the mesophyll or irrigated in Sodium Hypochlorite solution (commercial bleach) for thirty minutes to two hours to bleach the leaf portions of recalcitrant species. In the former approach, tissue disintegration was indicated by bubbles and the epidermides were transferred into petri dishes containing water for cleansing and then, separated with forceps. Tissue debris was cleared off the epidermides with fine-hair brush and wash in several changes of water. Drops of different grades of Ethanol $75 \%$ up to $100 \%$ added in turn to harden the cells.

Preparations were later stained with safranin $\mathrm{O}$ in $50 \%$ alcohol for about five minutes before mounting in glycerin on the glass slide. The epidermides were mounted with the uppermost surface facing up, covered with cover-slips and ringed with nail varnish to prevent dehydration. Then the slides were appropriately labeled. Slides were examined with light microscope at x100, and $\mathrm{x} 400$. Photomicrographs were taken using Topview 3.2 Image Camera attached to a microscope and computer.

\section{Results}

Summary of all findings is presented in Figures 1 and 2, and Table 2. 
Table 2. Comparative qualitative characters of the foliar epidermis of Isolona species

\begin{tabular}{|c|c|c|c|c|c|c|}
\hline Species & Surface & $\begin{array}{c}\text { Epidermal cell } \\
\text { shape }\end{array}$ & $\begin{array}{c}\text { Anticlinal wall } \\
\text { pattern }\end{array}$ & $\begin{array}{c}\text { Stomata } \\
\text { type }\end{array}$ & $\begin{array}{c}\text { Trichome } \\
\text { type }\end{array}$ & Crystals \\
\hline \multirow{2}{*}{ I. campanulata } & Adaxial & $\begin{array}{c}\text { Irregular, } \\
\text { beaded }\end{array}$ & Curved & - & - & - \\
\hline & Abaxial & $\begin{array}{c}\text { Irregular, } \\
\text { beaded }\end{array}$ & Curved & $\begin{array}{c}\text { Paracytic, } \\
\text { brachyparacytic }\end{array}$ & - & - \\
\hline \multirow[b]{2}{*}{ I. congolana } & Adaxial & Polygonal & Straight & - & - & - \\
\hline & Abaxial & Polygonal & Straight-curved & $\begin{array}{c}\text { Paracytic, } \\
\text { brachyparacytic }\end{array}$ & - & - \\
\hline \multirow[b]{2}{*}{ I. dewevrei } & Adaxial & Irregular & Straight-curved & - & - & Present \\
\hline & Abaxial & $\begin{array}{c}\text { Polygonal, } \\
\text { beaded }\end{array}$ & Undulate & Paracytic & - & Present \\
\hline \multirow{2}{*}{ I. hexaloba } & Adaxial & Polygonal & Curved & - & $\begin{array}{l}\text { Trichome } \\
\text { base found }\end{array}$ & $\begin{array}{l}\text { Present } \\
\text { as sands }\end{array}$ \\
\hline & Abaxial & $\begin{array}{l}\text { Irregular, } \\
\text { beaded }\end{array}$ & Undulate & $\begin{array}{c}\text { Paracytic, } \\
\text { brachyparacytic }\end{array}$ & - & - \\
\hline \multirow[b]{2}{*}{ I. pleurocarpus } & Adaxial & Polygonal & Curved & - & - & Present \\
\hline & Abaxial & Irregular & Undulate & $\begin{array}{c}\text { Paracytic, } \\
\text { brachyparacytic }\end{array}$ & - & - \\
\hline \multirow{2}{*}{ I. thonneri } & Adaxial & $\begin{array}{l}\text { Irregular, } \\
\text { beaded }\end{array}$ & Undulate & 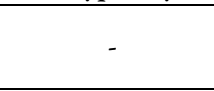 & - & - \\
\hline & Abaxial & Irregular & Undulate & $\begin{array}{c}\text { Paracytic, } \\
\text { brachyparacytic }\end{array}$ & - & - \\
\hline \multirow[b]{2}{*}{ I. zenkeri } & Adaxial & Irregular & Curved & - & - & - \\
\hline & Abaxial & $\begin{array}{c}\text { Irregular, } \\
\text { beaded }\end{array}$ & Undulate & $\begin{array}{c}\text { Paracytic, } 1+2 \\
\text { laterocytic }^{*}\end{array}$ & - & - \\
\hline
\end{tabular}

${ }^{*}=$ stomatal type in the sense of Carpenter (2005).

Across the species, the interstomatal number is not constant; it varies from 1-5 (Figures 1 and 2) while stomatal aperture appeared usually narrower than wider in the genus. The guard cells usually lie parallel to the long axis of the subsidiary cells. The leaves are hypostomatic and paracytic stomatal type is typical. Other stomatal types such as brachyparacytic and 1+2 laterocytic type may accompany this basic type (Figure 3). The non-stomatal cells such as epidermal cells have closely varied wall thickness across the species. Cell shape may be irregular on both surfaces in I. campanulata, (Figure 1 A, B; Table 2), I. thonneri (Figure 2C, D; Table 2) and I. zenkeri (Figure 2E, F; Table 2) while polygonal cell shape was found on both surfaces of the epidermis in I. congolana (Figures 1C, D; Table 2) only. Beaded ornamentation was observed on the epidermal cells of $I$. thonneri on the adaxial surface (Figure 2C, Table 2) whereas on the abaxial surface, it was observed in $I$. dewevrei (Figure 1F, Table 2) but I. campanulata has beaded ornamentation on the epidermis on both surfaces (Figure 1A, B, Table 2). Other species have different cell shape which may be irregular or polygonal.

Under light microscope, the anticlinal walls of the epidermis in Isolona varied from curved, straight, undulate and straight-curved (Figures 1, 2, Table 2). Three of the species namely I. hexaloba, I. pleurocarpus and I. zenkeri are curved and undulate anticlinal wall in adaxial and abaxial respectively. On the upper and lower region $I$. campanulata has curved while $I$. thonneri has undulate wall pattern. Straight anticlinal wall is visible only in adaxial region of $I$. congolana.

Crystals of calcium oxalate may be found as flakes in I. dewevrei on both surfaces (Figure 1E, F, Table 2 ) or restricted to the adaxial surface in I. pleurocarpus (Figure 2B, Table 2). Crystals occurred as sands in $I$. hexaloba on the adaxial surface only (Figure $1 \mathrm{G}$; Table 2). The species appear glabrous but trichome base was recorded in I. hexaloba (Figure $1 \mathrm{H}$, Table 2). 

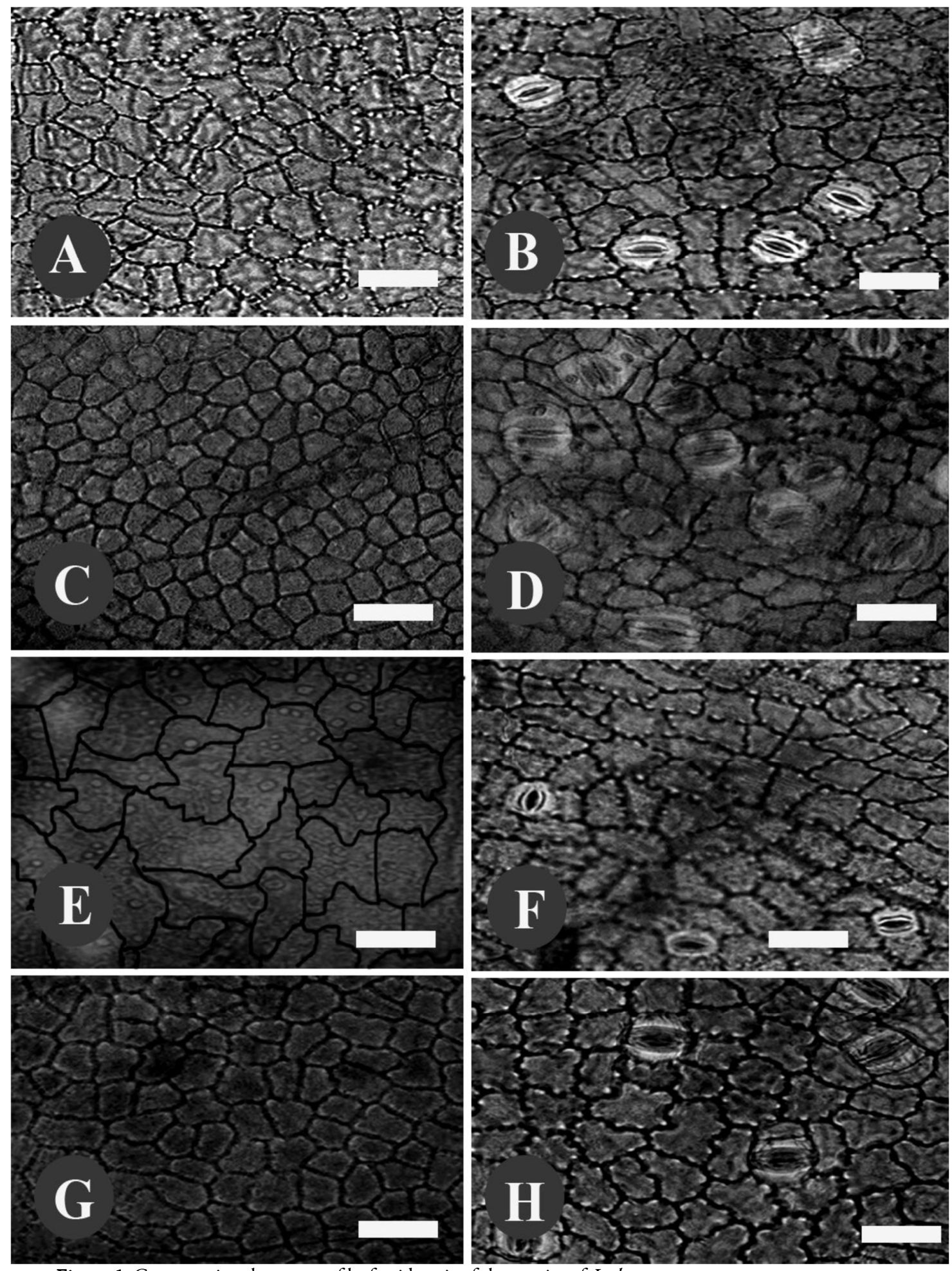

Figure 1. Comparative characters of leaf epidermis of the species of Isolona

A, C, E and G: Adaxial surfaces- B, D, F and H: Abaxial surfaces- A, B-Isolona campanulata, C, D- I. congolana. E, F-

I. dewevrei $\mathrm{G}, \mathrm{H}-$ I. hexaloba

Scale bar- $25 \mu \mathrm{m}$. 

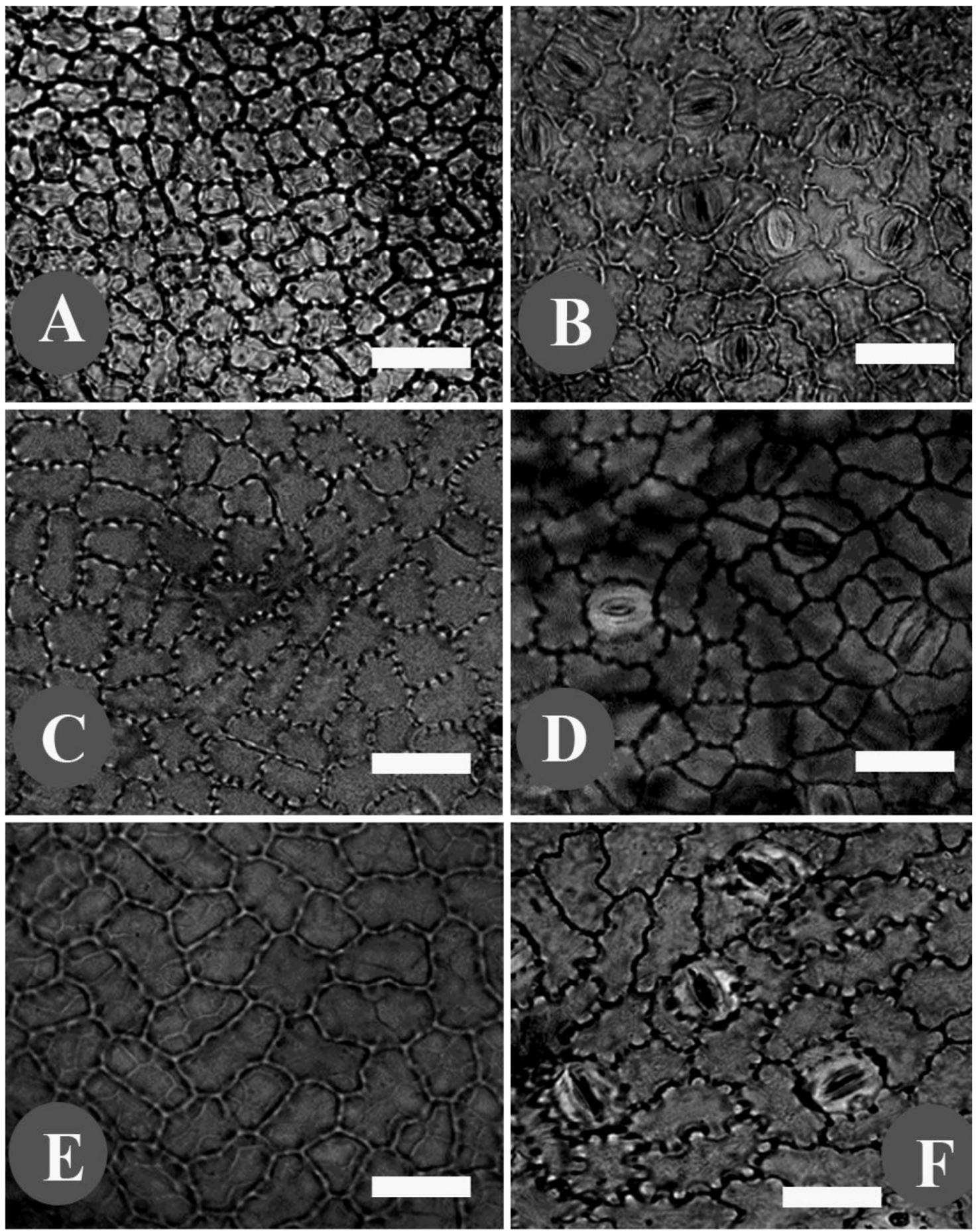

Figure 2. Comparative characters of leaf epidermis of the species of Isolona

A, C and E: Adaxial surfaces, B, D and F: Abaxial surfaces. A, B-Isolona pleurocarpus, C, D- I. thonneri, E, F- I. zenkeri Scale bar- $25 \mu \mathrm{m}$. 

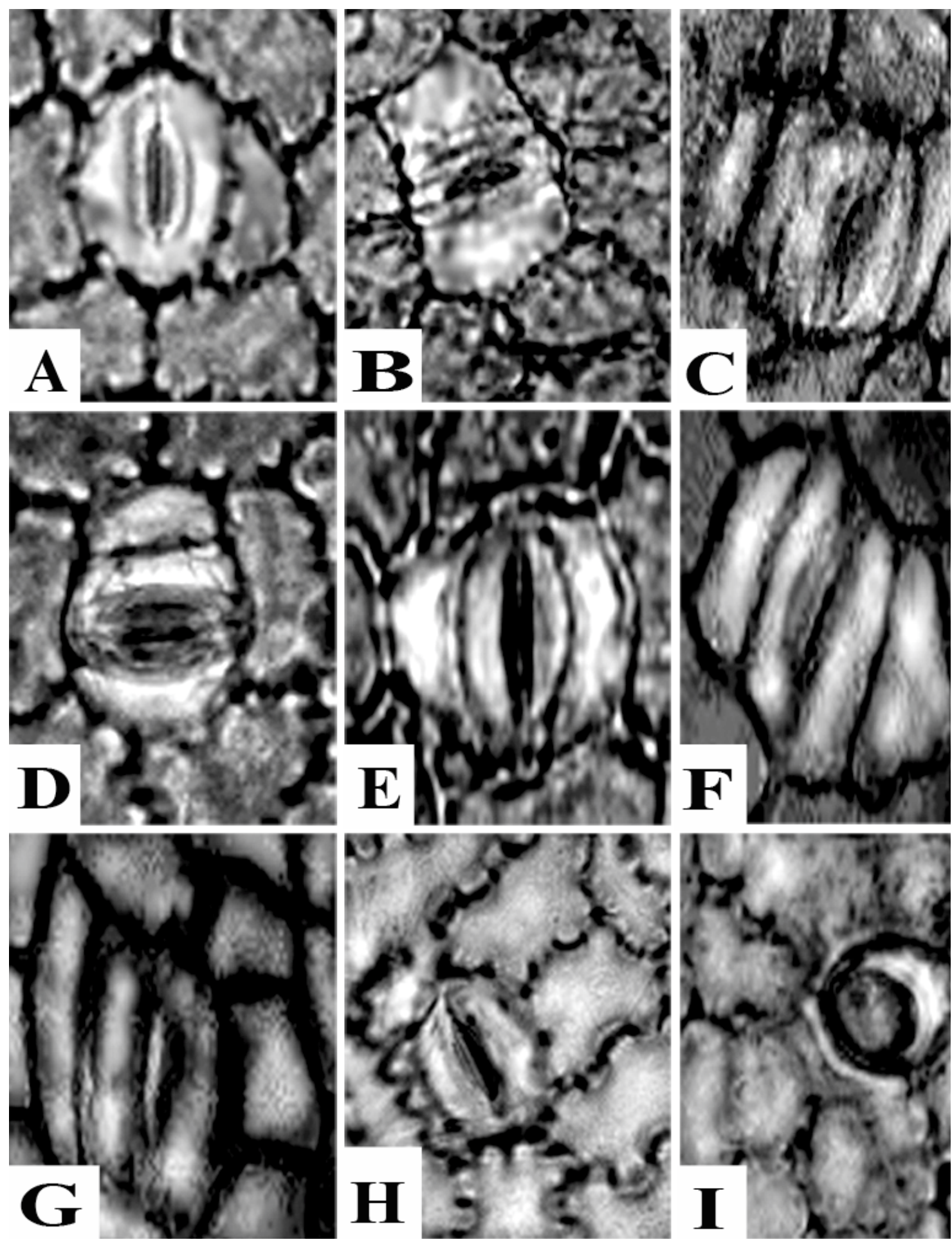

Figure 3. Diagnostic stomatal types and trichome base found in the species of Isolona

A = Paracytic, this common to all the species. B-G: Brachyparacytic type found in I. campanulata, I. congolana, I. hexaloba, I. pleurocarpus and I. thonneri. H: $1+2$ laterocytic type, sensu Carpenter (2005). I: Trichome base found in I. hexaloba. 


\section{Discussion}

The foliar epidermis is one of the most noteworthy taxonomic characters from the biosystematic point of view and the taxonomic studies of a number of families are made on the basis of leaf epidermis (Stace, 1984; Baranova, 1992). Contrasting and comparing the epidermal characters of Isolona, it revealed relationship among the species. Polygonal and irregular cell shape is seen in all on both surfaces. This study is in agreement with the report of Pereira-Sheteolu (1992) on genus Monodora, the sister genus to Isolona. The Annonaceae studies according to Metcalfe and Chalk (1950); Michael and James (2012); Olowokudejo (1990); indicated confinement of paracytic stomata to the abaxial surface in the family, but complexity in stomata apparatus of Annonaceae is first reported by Metcalfe and Chalk (1950) who for saw the possibilities of the stomata having more than one pair of subsidiary cells. The subsidiary cells surrounding the stomata in this study are obviously different from each other which aid to classify into different stomata types. This investigation revealed $I$. campanulata, I. congolana, I. hexaloba, I. thonneriand I. pleurocarpus recorded brachyparacytic accompanying paracytic stomata and a new record laterocytic stoma present in I. zenkeri.

The presence or absence of trichomes can frequently be used to delimit species, genera, or the whole family (Metcalfe and Chalk, 1979). Theobbald et al. (1979) established the importance of trichomes in comparative systematic of angiosperm. A number of reports on Annonaceae suggested the presence of unicellular unbranched trichomes (Metcalfe and Chalk, 1950; 1979; Olowokudejo, 1990; Michael and James, 2012). The presence of glandular base trichomes on the abaxial is diagnostic in I. hexaloba. Olowokudejo (1990) reported wax of various size, shapes and pattern in Annona. Base on the presented Table 2, the stomata type of I. campanulata and I. congolana differ from each other beyond that epidermal cell shape in $I$. campanulata is irregular on both surfaces while it is polygonal in $I$. congolana. Epidermal cells are larger in $I$. congolana compare to I. campanulata. The quantitative characters also indicated significantly difference from one another. I. pleurocarpus and I. hexaloba show distinct differences between themselves ranging from stomata type, present of druses and number of the cell per field.

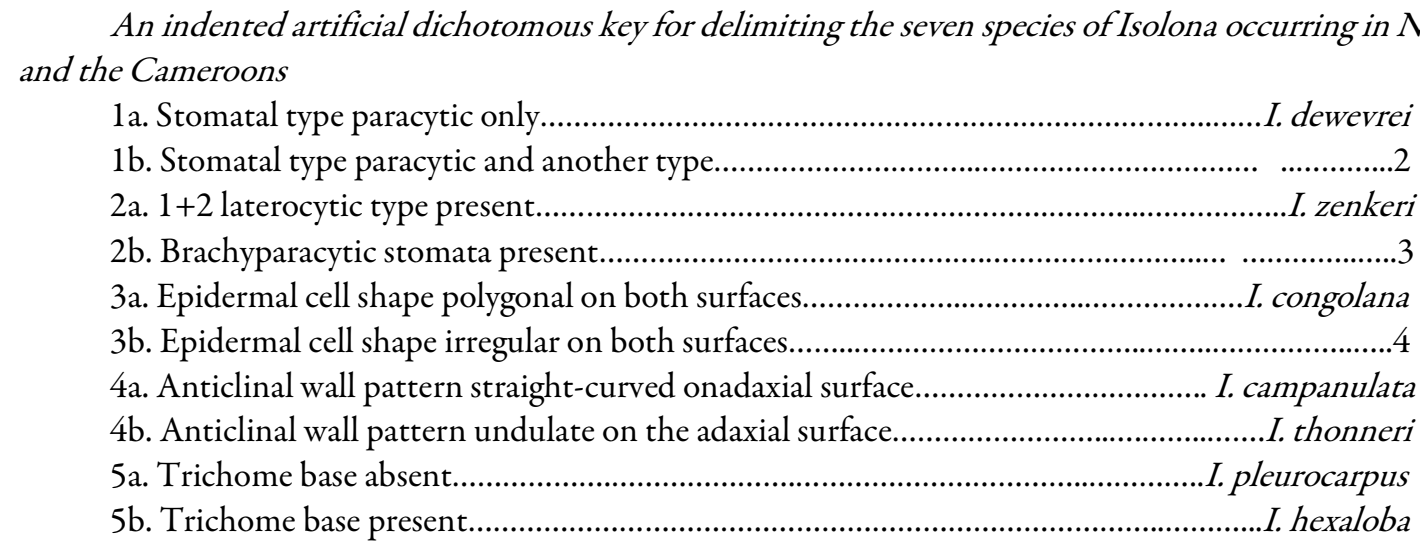

\section{Conclusions}

The foliar epidermal assessment provided a significant source of information and evidence in determining the interrelationship among the seven Isolona species occurring in Nigeria and the Cameroons. The study revealed similar and different characters used for separating the species within the genus. Some of the diagnostic characters used for delineating the genus were stomatal type, presence or absence of hair, epidermal cell shape, and anticlinal wall pattern. Hypostomatic leaves and paracytic stomatal types that generic constant. Complex stomata types were present in the genus with the possession of $1+2$ laterocytic type stomatal as a new record. 


\section{Authors' Contributions}

ABK and JDO contributed to manuscript development and literary work as supervisors of ASA who did data acquisition, writing and laboratory work. All authors read and approved the final manuscript.

\section{Acknowledgements}

This research received no specific grant from any funding agency in the public, commercial, or not-forprofit sectors.

\section{Conflict of Interests}

The authors declare that there are no conflicts of interest related to this article.

\section{References}

APG II (2003). An update of the angiosperm phylogeny group classification for the orders and families of flowering plants: APG II. Botanical Journal of the Linnean Society.141:399-436 https://doi.org/10.1046/j.1095-8339.2003.t011-00158.X

Ayodele AE (2000). Systematics studies in the family Polygonaceae. Ph.D. Thesis University of Lagos, Nigeria pp 239.

Baranova M (1972). Systematic anatomy of the leaf epidermis in the Magnoliaceae and some related families. Taxon 21(4):447-469.

Bremer B, Bremer K, Chase MW (2009). An update of the angiosperm phylogeny group classification for the orders and families of flowering plants: APG III. Botanical Journal of the Linnean Society 161:105-121.

Carpenter KJ (2005). Stomatal architecture and evolution in basal angiosperms. American Journal of Botany 92:15951615. https://doi.org/10.3732/ajb.92.10.1595

Couvreur TL, Gereau RE, Wieringa JJ, Richardson JE (2006). Description of four new species of Monodora and Isolona (Annonaceae) from Tanzania and an overview of Tanzanian Annonaceae diversity. Adansonia 28(2):243-266.

Couvreur TL (2009). Monograph of the syncarpous African genera Isolona and Monodora (Annonaceae). Systematic Botany Monographs 87:1-150. https://www.jstor.org/stable/25592354

Couvreur TL, Maas PJM, Meinke S, Johnson DM, Kebler PJA (2012). Keys to the genera of Annonaceae. Botanical Journal of the Linnean Society 169:74-83. https://doi.org/10.1111/j.1095-8339.2012.01230.x

Couvreur TL, Richardson JE, Sosef MSM, Erkens RHJ, Chatrou LW (2008). Evolution of syncarpy and other morphological characters in African Annonaceae: a posterior mapping approach. Molecular Phylogenetics and Evolution 47:302-318. https://doi.org/10.1016/j.ympev. 2008.01.018

Gottsberger G, Meinke S, Porembski S (2011). First records of flower biology and pollination in African Annonaceae: Isolona, Piptostigma, Uvariodendron, Monodora and Uvariopsis. Flora 206:498-510. https://doi.org/10.1016/j.flora.2010.08.005

Holmgren P, Holmgren N (2003). Index Herbariorum (on line). Retrieved from http://www.nybg.org/bsci/ih/ih.html

Kadiri AB (2003). Foliar epidermal morphology of the medicinal genus Momordica Linn, (Cucurbitaceae) in Nigeria. Nigerian Journal of Science 37(10):25-33.

Maas PJM, Westra LYT, Chatrou LW (2003). Duguetia. Flora Neotropica Monograph. The New York Botanical Garden, New York pp 1-274.

Metcalfe CR, Chalk L (1950). Anatomy of the dicotyledons. Oxford University Press, Oxford, pp 724.

Metcalfe CR, Chalk L (1979). Anatomy of the dicotyledons (2nd ed.). Vol. 1. Oxford University Press, Oxford pp 276.

Michael DP, James AD (2012). Dating clades with fossils and molecules: the case of Annonaceae. Botanical Journal of the Linnean Society 169:84-116. https://doi.org/10.1111/j.1095-8339.2012.01234.X 
Ogundipe OT, Olatunji OA (1991). The leaf anatomy of the species of Cochlospermum Kunth (Cochlospermaceae) in West Africa. Feddes Repertorium 102(34):183-187. https://doi.org/10.1002/fedr.19911020306

Olowokudejo JD (1990). Comparative morphology of leaf epidermal of genus Annona (Annonaceae) in West Africa. Phytomorphology 40(3\&4):407-422.

Olowokudejo JD (1993). Comparative epidermal morphology of West African species of Jatropha L. (Euphorbiaceae). Botanical Journal of the Linnean Society 111:139-154. https://doi.org/10.1111/j.1095-8339.1993.tb01896.x

Pereira-Sheteolu OA (1992). Taxonomy of medicinal plants: Foliar epidermal characters in the genus Monodora (Annonaceae). Feddes Repertorium 103(5-6):375-379. https://doi.org/10.1002/fedr.19921030516

Richardson JE, Chatrou LW, Mols JB, Erkens RHJ, Pirie MD (2004). Historical biogeography of two cosmopolitan families of flowering plants: Annonaceae and Rhamnaceae. Philosophical Transactions of the Royal Society of London, Series B: Biological Sciences 359:1495-1508. https://doi.org/10.1098/rstb.2004.1537

Smith SA, Beaulieu JM, Donoghue MJ (2010). An uncorrelated relaxed-clock analysis suggests an earlier origin for flowering plants. Proceedings of the National Academy of Science of the United States of America 107:58975902. https://doi.org/10.1073/pnas.1001225107

Stace CA (1965). Cuticular studies as an aid to plant taxonomy. Bulletin of the British Museum (Natural History) 4:378.

Theobald JLW, Krahulic JL, Rollins RC (1979). Trichomes description and classification. In: MetcalfCR, Chalk L (Eds.). Anatomy of the Dicotyledons, $2^{\text {nd }}$ Edition, Vol. 1, Oxford, Clarendon Press pp 40-53.

Zeng L, Zhang Q, Sun R, Kong H, Zhang N, Ma H (2014). Resolution of deep angiosperm phylogeny using conserved nuclear genes and estimates of early divergence times. Nature Communications 5956:1-12 https://doi.org/10.1038/ncomms5956

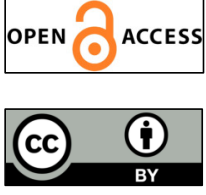

The journal offers free, immediate, and unrestricted access to peer-reviewed research and scholarly work. Users are allowed to read, download, copy, distribute, print, search, or link to the full texts of the articles, or use them for any other lawful purpose, without asking prior permission from the publisher or the author.

License - Articles published in Notulae Scientia Biologicae are Open-Access, distributed under the terms and conditions of the Creative Commons Attribution (CC BY 4.0) License.

(c) Articles by the authors; SHST, Cluj-Napoca, Romania. The journal allows the author(s) to hold the copyright/to retain publishing rights without restriction. 